\title{
Upgrading Climate Policy from Simplistic Decarbonization Recommendations to a Comprehensive Carbon Management
}

\author{
Stefan P. Schleicher \\ Wegener Center for Climate and Global Change, University of Graz, Graz, Austria \\ Received December 12, 2016; accepted December 12, 2016; published online January 13, 2017
}

\begin{abstract}
By taking stock of the current state of climate policy, we conclude that both energy policy and the closely tied climate policy deserve an upgrade from level 1.0 to 2.0. There are many reasons which motivate this shift. International climate policy, despite the hailed Paris Agreement of 2015, is still lacking credible commitments. Only a last minute effort for ratifying this agreement before it entered into force saved the European Union from a disgraceful loss of face. Meanwhile, however, we observe record highs both in global temperatures and concentration of greenhouse gases in the atmosphere. In view of this rather shaky state of climate policy, we elaborate the proposition that decisions about energy and climate will be less forged by policy decisions but rather driven by disruptive innovations backed by business interests.
\end{abstract}

Keywords: Energy policy, Climate policy, Paris Agreement

Ein Upgrading für die Klimapolitik von simplistischen Empfehlungen für Dekarbonisierung zu einem umfassenden Carbon Management

Zusammenfassung: Eine Bestandsaufnahme des aktuellen Zustands der Klimapolitik lässt uns schließen, dass sowohl die Energiepolitik als auch die eng verknüpfte Klimapolitik ein Upgrade vom Level 1.0 auf 2.0 verdienen. Viele Gründe motivieren diesen Schritt. Der internationalen Klimapolitik fehlen trotz der bejubelten Pariser Vereinbarung von 2015 immer noch glaubwürdige Klimaschutzzusagen. Nur durch eine Kraftanstrengung in letzter Minute gelang es der Europäischen Union, diese Vereinbarung vor deren Inkrafttreten zu ratifizieren und dadurch einen Gesichtsverlust durch eine

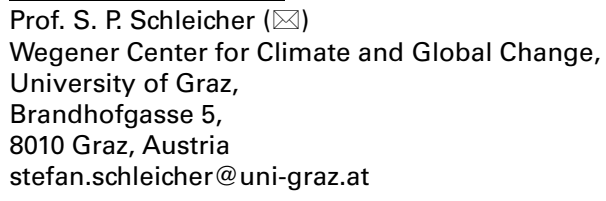

Blamage abzuwenden. Inzwischen beobachten wir jedoch Rekordwerte bei den globalen Temperaturen und der Konzentration von Treibhausgasen in der Atmosphäre. Im Hinblick auf diesen eher labilen Zustand der Klimapolitik entwickeln wir Aussagen, dass die Entscheidungen über Energie- und Klima künftig weniger von politischen Prozessen sondern eher von disruptiven Innovationen gestalten werden, die wiederum durch Business-Interessen unterstützt werden.

Schlüsselwörter: Energiepolitik, Klimapolitik, Pariser Abkommen

\section{Introduction}

Several events recommend taking stock and assessing the current state of climate policy, which is closely tied to energy policy. The latest episode is the turnaround in the related policy design of the United States by the Trump administration. This decisive policy change by the second biggest greenhouse gas emitter might overshadow increasing internal conflicts by the third biggest emitter, the European Union, which struggles with making its targets for emissions, renewables, and energy efficiency effective. Then there is emerging evidence that the Paris Agreement [1], the hailed global climate treaty that was adopted in 2015 and became effective only a year later, is extremely vulnerable because of its fully voluntary design.

We start with a reflection of the current state of climate policy and come up with second thoughts about the seeming progress in emissions reductions and policy commitments. By providing empirical evidence about the drivers of emissions in China, the United States, and the European Union, we prepare the ground for upgrading our understanding of climate and energy policy from level 1.0 to 2.0. 


\section{A Second View on Climate Policy}

The dynamics of climate change, the reported evidence about it, and the policy responses seem to be simple at a first glance but turn out to be increasingly sobering after a second view.

\subsection{Signs of Seeming Progress}

At a first glance, we might discover signs of an encouraging progress: Global greenhouse gas emissions appear to have been stable over the past three years; China, the biggest emitter, might already have peaked its emissions; the European Union reached its 20 percent emissions reduction target for 2020 by achieving a 24 percent decline compared to 1990 already in 2015 [2]. A second view, however, reveals evidence of increasing concern [3]. What might at first look like an indicator of structural changes towards a lowenergy and low-carbon economy actually reflects the ongoing economic slowdown in the industrialized countries - like the United States and the European Union - that has hit China's exports.

International climate policy seems to have succeeded in 2015 with the Paris Agreement, a second try after the illfated Kyoto Protocol of 1997. This new international climate agreement put forward goals of keeping global warming "well below" $2^{\circ} \mathrm{C}$ and to "pursue efforts" to limit warming to $1.5^{\circ} \mathrm{C}$ above pre-industrial levels by the end of the century. The current commitments of the countries, contained in the so-called Nationally Determined Contributions (NDCs), would lead to temperature increases beyond $3^{\circ} \mathrm{C}$.

\subsection{Climate Policy at the Cross-Roads}

With the election of Donald Trump in the United States as the next president, who has openly questioned the merits of any climate policy, the prospects of a global multilateral climate strategy have become doomed again. These rather discouraging prospects coincide with the fact that 2016 was the year with the warmest global surface temperature since instrument based measurements are available.

Thus, the interim result of this stock taking is rather sobering, since the gap between the need for actions and the effective policy decisions seems to be widening. A Pentagon report [4] states that "Global climate change will have wide-ranging implications for U.S. national security interests over the foreseeable future because it will aggravate existing problems - such as poverty, social tensions, environmental degradation, ineffectual leadership, and weak political institutions - that threaten domestic stability in a number of countries."

Continuing this stock taking in the arena of policy making reveals even more signs of concern. International climate policy, despite the Paris Agreement of 2015, is still lacking credible commitments. Only a last minute effort for ratifying this agreement before it entered into force saved the European Union from a disgraceful loss of face. The European Emissions Trading System (EU ETS) is far from its intended role as the pillar of EU climate policy [5]. Ongoing efforts for a decisive reform so far have failed because of the diverging interests of Member States. The EU roadmaps for 2050 [6] seem to have lost their momentum.

\section{Scanning the Facts}

Many controversies about the design of energy and climate policy seem to be ill-fated because of the lack of evidencebased facts. This is in particular visible when the discussions focus on targets before sufficient knowledge is acquired on how these targets could be achieved.

\subsection{The Size of the Problem}

A brief summary of the facts of climate change serves as a reminder of the size of the problem. In 2016 concentration of carbon dioxide in the atmosphere passed the 400 ppm threshold, a 42 percent increase compared to pre-industrial levels that is, in the scientific community, almost unanimously considered as the trigger for the currently observable climate change. 2016 is the hottest year on record, topping the record temperatures in the past decades and outpacing any temperature increase in the past thousand years. These temperature anomalies are accompanied by extreme weather events, sea level rise, disappearance of Polar sea ice, unprecedented coral bleaching, and disruptions in the food chains.

It is these facts about climate change which motivate efforts for abating greenhouse gas emissions and adapting to inevitable climate change. The European Union, e.g., is committed to reducing these emissions by at least 40 percent by 2030 compared to 1990 levels. This is considered as a milestone of the European Council decision in 2009, to reduce emissions by 80 - 95 percent by 2050 compared to 1990 volumes [5]. But the question remains if there is any plausibility for achieving such a radical change in life styles and economic activity that would be compatible with these goals.

\subsection{Essentials on the Drivers of Energy Use and Emissions}

Debates about climate policy too often start with haggling about decarbonization targets without supplying strategies that would underpin these targets. We provide therefore at least some essential tools for a more credible argumentation.

Carbon emissions are ultimately driven by the choice of technologies and the level of economic activity. This can be explained by the following analytical relationship:

1. (emissions) $=$ (emissions intensity) $\mathrm{x}$ (energy intensity) $x$ (economic activity) with (emissions intensity) := (emissions)/(energy) (energy intensity) := (energy)/(economic activity) 


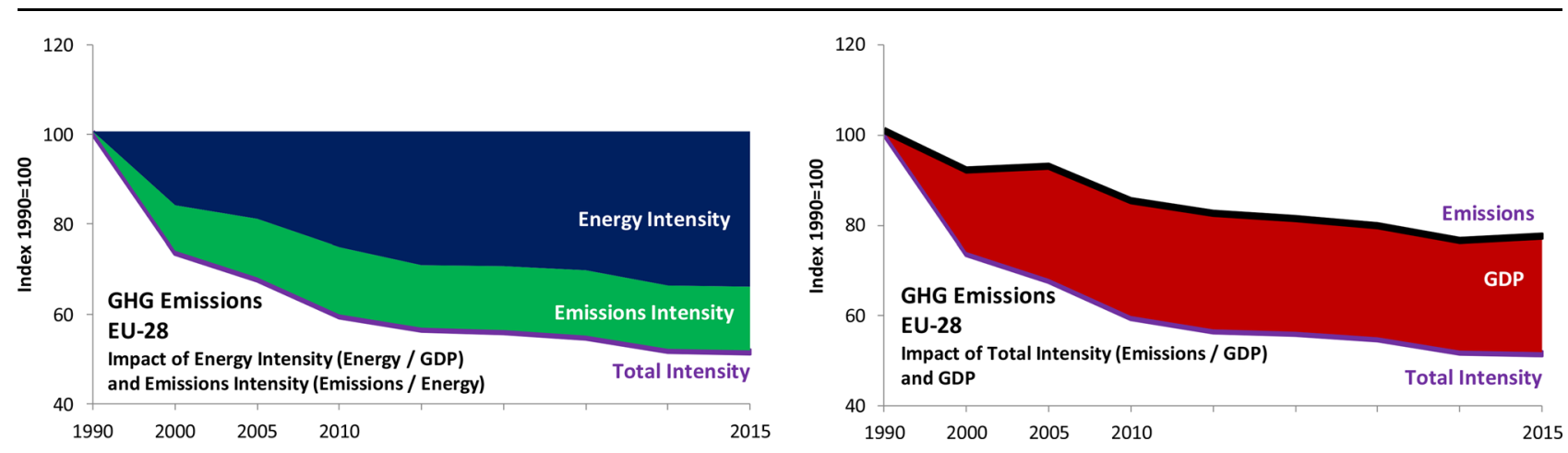

Figure 1: Greenhouse gas emissions of EU-28-impact of technologies and economic activity (Own calculations based on Eurostat data)
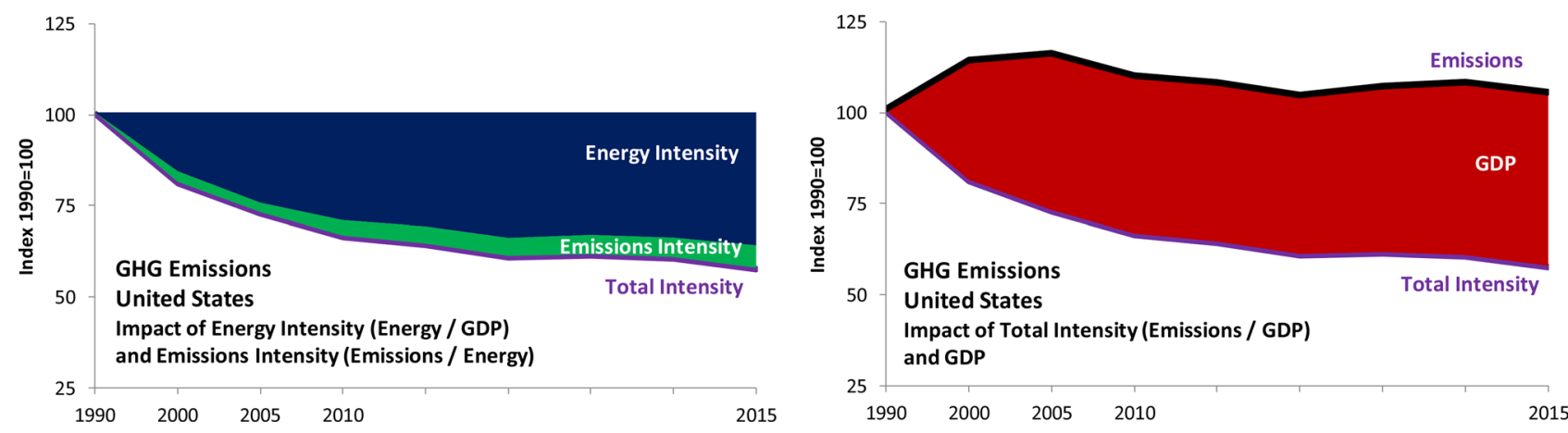

Figure 2: Greenhouse gas emissions of United States-impact of technologies and economic activity (Own calculations based on Eurostat data)
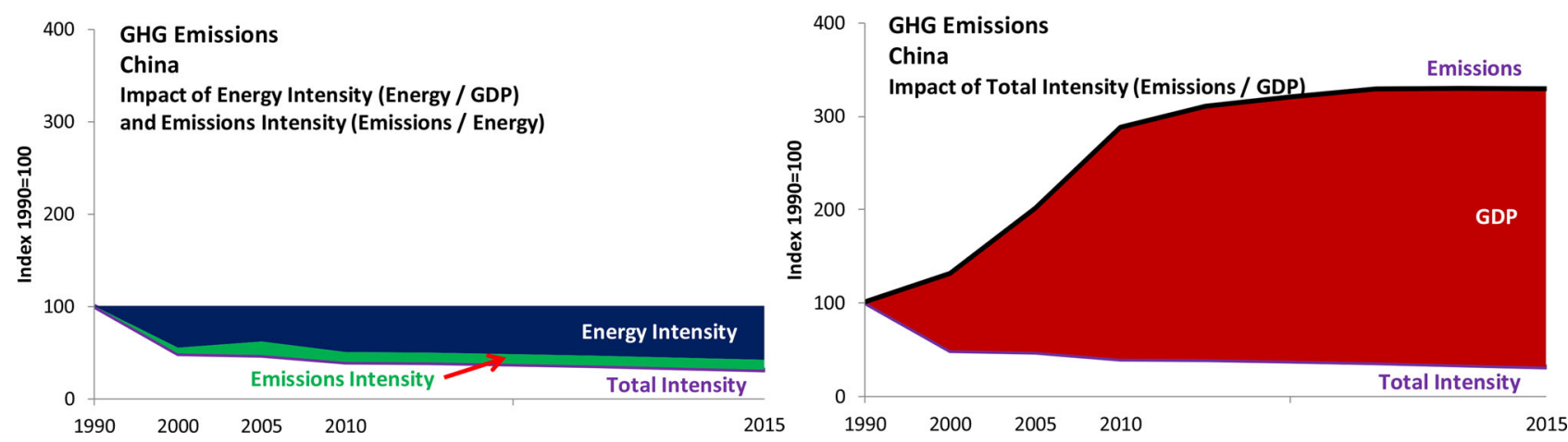

Figure 3: Greenhouse gas emissions of China-impact of technologies and economic activity (Own calculations based on Eurostat data)

We rewrite (1) by

2. (emissions) $=($ total intensity $) \times$ (economic activity) with (total intensity) := (emissions intensity) $x$ (energy intensity) $=$

$=($ emissions $) /($ economic activity $)$

The energy intensity is a measure for energy efficiency. The emissions intensity reflects the carbon intensity of the energy mix, i.e. the composition of fossil fuels and the share of renewables and nuclear energy. These relationships hold for any type and scale of economic activity. We are considering national scales with economic activity measured by gross domestic product (GDP) in volume terms. These relationships can be visualized in graphs that reveal a lot about the drivers of greenhouse gas emissions.

We start with evidence for the European Union in Figure 1. The left chart indicates that the total intensity of emissions declined by 49 percent between 1990 and 2015, which results from a 35 percent reduction of the energy intensity and a 14 percent reduction of the emissions intensity. The right chart adds to the reducing impact of the total intensity the expanding impact of economic activity measured by GDP, which grew by 25 percent between 1990 and 2015. Adding to the positive GDP growth, the negative total intensity impact explains the decline of emissions of 24 percent after 1990. Obviously the main driver for emission reduction in the European Union is the improvement of energy intensity, which is mainly due to the vast poten- 

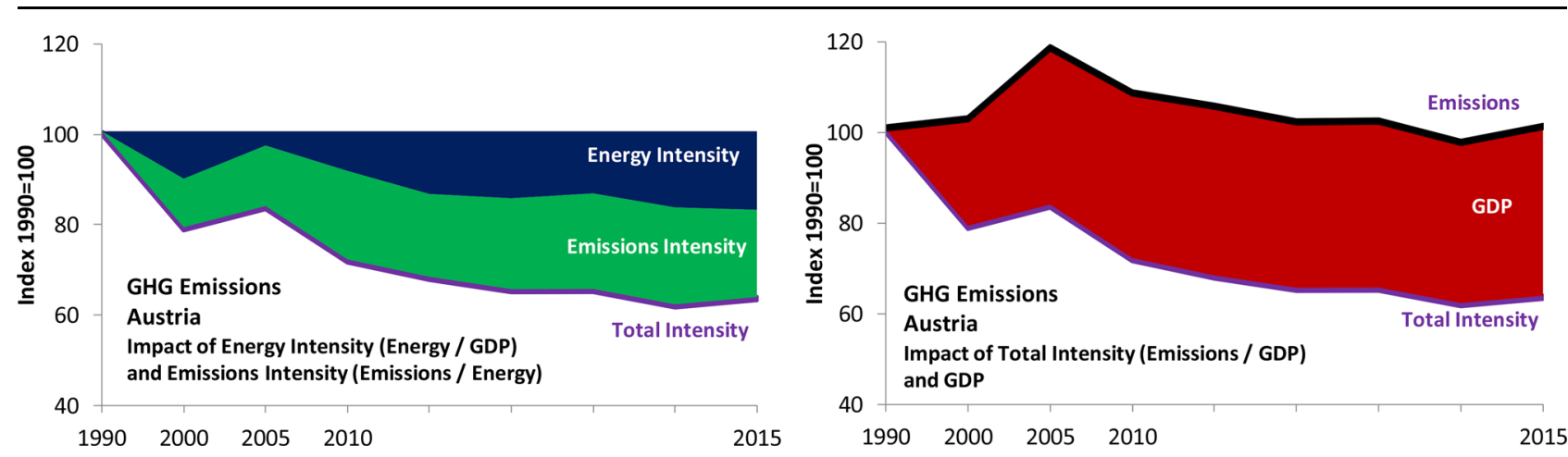

Figure 4: Greenhouse gas emissions of Austria-impact of technologies and economic activity (Own calculations based on Eurostat data)

Figure 5: Technologies and economic activity as drivers of greenhouse gas emissions (Own calculations based on Eurostat data)

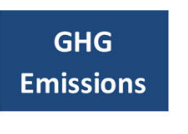

$\begin{array}{cc}\text { Energy } & \text { Emissions } \\ \text { Intensity } & \text { Intensity }\end{array}$

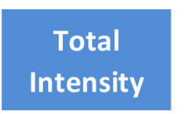

Percentage change between 1990 and 2015

EU-28
Austria
Germany
United Kingdom
Italy
France
Poland
Spain
Netherlands
Czech Republic
Switzerland
United States
China

-24
0
-27
-37
-16
-15
-18
23
-13
-37

$\begin{array}{ll}-35 & -1 \\ -17 & -2 \\ -37 & -12 \\ -45 & -17 \\ -13 & -15 \\ -25 & -17 \\ -62 & -5 \\ -20 & -5 \\ -29 & -18 \\ -52 & -11 \\ -29 & -10 \\ -37 & -6 \\ -58 & -11\end{array}$

-14
-20
-12
-17
-15
-17
-5
-5
-18
-11

-10
-6
-11

-49
-37
-49
-62
-28
-42
-66
-25
-47
-63
-39
-43
-69

25

37

22

25

12

27

48

48

33

26

28

47

298 tial for improving the energy efficiency in the new Member States.

Figure 2 provides a similar analysis for the United States. The left chart reveals that the 43 percent decline of the total intensity results from a 37 percent improvement of energy intensity but only a 6 percent contribution of emissions intensity because of the rather modest impact of renewables so far. The right chart adds to the total intensity the impact of the substantial 48 percent GDP growth, thus causing a 5 percent increase of emissions.

China exhibits, as can be seen from Figure 3, a completely different emissions path. Total intensity has declined by 69 percent because of a 58 percent reduction of energy intensity and a 11 percent reduction of emissions intensity. Outstanding, however, is the almost triplication of GDP by 298 percent. This explains the 229 percent increase of China's emissions over the past 26 years. The remarkable big improvement of energy efficiency in China is still not matched by a similar improvement in the emissions intensity despite heavy investments into renewables.
For comparison we add Austria in Figure 4. Our analysis reveals that Austria could only keep emissions stable between 1990 and 2015, since the 37 percent GDP expansion was matched by the same improvement of the total intensity of emissions. In contrast to all other countries listed in Figure 5, Austria exhibits a higher improvement in the emissions intensity than in the energy intensity. This might hint to policies that give more emphasis to renewables than to energy efficiency policies.

We complement our analysis of the drivers for greenhouse gas emissions with Figure 5, which, apart from the top emitters of the European Union, includes also Austria and Switzerland together with the United States and China. A careful interpretation of the numbers is needed. In Poland and the Czech Republic, the high decline in energy intensity is due to the high potential for energy efficiency, but in the United Kingdom also due to relocation of energy intensive industries. Together with the Netherlands, Austria excels in shifting the energy mix to renewables. Despite having coined the term "Energiewende", Germany has still a high 
potential for improving its emissions intensity because of the heavy dependence on coal for electricity generation.

\section{Switching Energy and Climate Policy from Level 1.0 to 2.0}

Our stock taking of the current state of energy and climate policy and the evidence-based insights about the ongoing transition in various countries give some guidance on how we could proceed, or to put it into a familiar wording, how we could switch energy and climate policy from level 1.0 to 2.0.

\subsection{Proposition 1: Rely not Only on International Policy Designs}

This proposition holds for the activities under the United Framework Convention of Climate Change with the Paris Agreement because of the fragility of its design and governance. This also holds for the energy and climate targets agreed upon in the European Union, since they represent rather the small set of common interests than ambitious efforts to move to a low-energy and low-emissions energy system. More ambitious Member States should have no problems in fulfilling their contributions within the EU framework.

\subsection{Proposition 2: Discover the Potential Benefits from Breakthrough Technologies}

It is not primarily the substitution of fossil energy by renewables but the emerging huge potential in application and transformation technologies which will drive the transition to low-energy and low-emissions structures [7]. The stock of buildings able to become, to a large extent, not only energy self-sufficient but also even net-suppliers of energy deserves priority. The current transport sector could evolve into a comprehensive mobility system with full-electrification being only one feature in an integration of all modes of mobility. Energy intensive industries, like steel and cement, need to be understood as suppliers of infrastructure for a low-energy and low-carbon economy.

\subsection{Proposition 3: Consider the Business Opportunities from Supporting the Transition to a Low-energy and Low-carbon Economy}

Extremely successful companies, like Apple, Google, and Amazon, demonstrate the potential of business opportunities that emerge in a phase of transition, be it tools for communication, access to information, or retailing goods and services. This is already visible in the switch to renewables which in 2015 outpaced fossils and nuclear by a ratio of 9 to 1 in installed new capacity [8]. Additive manufacturing, better known as 3D printing, will be a disruptive factor for industrial production. Sharing capital intensive goods such as cars will change the idea of ownership in particular if these cars become self-driving.

It will be the discovery of these business opportunities and their comprehensive carbon management which will be the ultimate driver to economic structures that are much more resource effective and in addition extremely low in emissions. This is at least a highly plausible perspective at the time when this paper is being written.

Open access funding provided by University of Graz.

Open Access This article is distributed under the terms of the Creative Commons Attribution 4.0 International License (http://creativecommons. org/licenses/by/4.0/), which permits unrestricted use, distribution, and reproduction in any medium, provided you give appropriate credit to the original author(s) and the source, provide a link to the Creative Commons license, and indicate if changes were made.

\section{References}

1. UNFCCC. The Paris Agreement. www.unfccc.int (1 December 2016)

2. European Environment Agency: Approximated EU greenhouse gas inventory - Proxy GHG emission estimates for 2015. EEA Report No 23/2016, 2016

3. Spencer, T.; Pierfederici, R.; Sartor, O.; Berghmans N.: State of the Low-Carbon Energy Union: Assessing the EU's progress towards its 2030 and 2050 climate objectives, IDDRI, 2016

4. Department of Defense: National Security Implications of ClimateRelated Risks and a Changing Climate, 2015

5. Schleicher, S.; Köppl, A.; Zeitlberger, A.: Extending the EU Commission's Proposal for a Reform of the EU Emissions Trading System, FEEM, 2016

6. European Commission: A Roadmap for moving to a competitive low-carbon economy in 2050, 2011

7. Deep Decarbonisation Pathways Project: Pathways to deep decarbonisation 2015 report, SDSN - IDDRI, 2015

8. World Economic Forum: Five reasons we should all be climate optimists. www.weforum.org, 2016 (1 December 2016) 